\section{Transdisciplinary EU science institute needs funds urgently}

Europe's future hinges on funding transdisciplinary scientific collaboration. But career paths, peer recognition, publication channels and the public funding of science are still mostly geared to maintain and reinforce disciplinarity.

We do not properly understand the effects of technology on the evolution of the systems on which we all depend. To take on global challenges such as climate change, growing urbanization and loss of biodiversity, we need to build a new science community that will explore common themes in natural, artificial and social systems.

The Santa Fe Institute in New Mexico, founded 25 years ago by scientists to create new sciences from combinations of the old, has changed science and technology by investigating how simple building blocks interact, from molecules to single cells to ecological systems to human communities. Singapore is developing a similar institute and so is Japan. They have caught on to the idea that today's world needs sciences recast for the future. They are investing in it. Europe is not - at least, not enough.

The Institute Para Limes, in doesburg, the Netherlands, follows the Santa Fe model and symbolizes the quintessence of the European Union (EU): a community without boundaries, national or disciplinary. It is endorsed by scientists, by leaders of the national science academies, by some companies and by highranking EU officials. They recognize that such a community cannot be built from within universities organized along disciplinary lines, or from institutes that serve national interests.

But this community is caught between two systems for funding research. In one, the EU pursues its goals through huge, bureaucratic Framework programmes - the seventh programme's budget is $€ 53.2$ billion (US\$72.4 billion) over seven years. Common interest is all, with no support for initiatives in individual member states. In the other system, member states use public money to pursue their own goals justified, in their view, by their payment of the EU's annual fee.

The yearly budget for the Institute Para Limes will be between $€ 6$ million and $€ 10$ million - too small on the EU scale to stimulate bureaucratic interest, but large enough on a national scale to be in competition with established institutes. Independent funding is urgently needed. We call on entrepreneurs, company executives, private foundations and visionary individuals for support.

Only then can we build on the institute's early promise and deliver a better understanding of systems that humanity needs for adequate food, energy, water and health without causing damage to the environment.

Jan W. Vasbinder Institute Para Limes, Doesburg, the Netherlands e-mail: jan.w.vasbinder@paralimes.org Bertil Andersson Nanyang

Technological University, Singapore

W. Brian Arthur Palo Alto Research

Center, California, USA

Maarten Boasson University of

Amsterdam, the Netherlands

Rob de Boer University of Utrecht, the Netherlands

Jean Pierre Changeux Institut Pasteur, France

Esteban Domingo Universidad

Autonóma de Madrid, Spain

Manfred Eigen Max Planck Institute for Biophysical Chemistry, Germany

Alan Fersht, Daan Frenkel, Martin

Rees University of Cambridge, UK Theo Groen Prisma \& Partners, the Netherlands

Robert Huber Max Planck Institute of Biochemistry, Germany

Tim Hunt London Research Institute,

Clare Hall Laboratories, UK

John Holland University of Michigan, USA

Robert May University of Oxford, UK Erling Norrby Royal Swedish Academy of Science, Sweden

Peter Nijkamp VU University
Amsterdam, the Netherlands Jean Marie Lehn ISIS, Université Louis Pasteur, France

Rudy Rabbinge, Marten Scheffer Wageningen University, the Netherlands

Peter Schuster University of Vienna, Austria

Ismail Serageldin Library of

Alexandria, Egypt

Jan Stuip Eindhoven University of

Technology, the Netherlands

Jan de Vries University of California,

Berkeley, USA

Wim van Vierssen Watercycle

Research Institute, Nieuwegein, the Netherlands

Rein Willems Dutch Senator, ex-chief executive, Shell Nederland, the

Netherlands

\section{The Rubisco enzyme and agricultural productivity}

Improving Rubisco's carbondioxide-fixing capability by genetic engineering is unlikely to enhance crop productivity significantly on its own (R. J. Ellis Nature 463, 164-165; 2010). Crop yield does not depend on a single enzymatic reaction: it is the result of a population-scale process that is the outcome of a series of source and sink regulated developmental and growth processes (R. K. M. Hay and J. R. Porter The Physiology of Crop Yield Wiley-Blackwell, 2006).

The success of modern, highyielding crop varieties is mainly down to their larger leaves, which intercept more light and provide more shade against competitive weeds. The management and agronomy of crops are typically more important as drivers of yield than genetics. They also make crop production more sustainable.

Crop physiologists have appreciated for a long time that to increase growth, increases in photosynthetic rate are accompanied by higher respiration costs because more growth substrates and more proteins have to be constructed. The idea that respiration and photorespiration are a drain on crop dry-weight production was dropped by crop physiologists many years ago.

Genomics, proteomics and metabolomics may increase our understanding of the regulation of different physiological processes and mechanisms of resistance to stress, but they do not show us the bigger picture. A recognition of the balance and interactions between genotype, environment and management is the intelligent solution to feeding the growing global population.

John R. Porter Department of Agriculture and Ecology, University of Copenhagen, 2630 Taastrup, Denmark email:jrp@life.ku.dk

Bernd Wollenweber Department of Agricultural Science, University of Århus, Denmark

\section{Parliament needs members who are scientifically literate}

One important factor is missing from your Editorial on batting for science in the current UK economic climate (Nature $\mathbf{4 6 3}$, 402; 2010): the need for scientists to engage more fully in the political arena, and, in particular, to stand for public office. Many new members of the UK Parliament after the 1997 general election had a scientific or medical background.

I am not suggesting a correlation between the large number of scientifically literate people in the House of Commons and the expansion in UK science budgets after 1997. But an ability to understand the nature of science and scientific methodologies could help our elected representatives to avoid ill-advised funding decisions. This would be particularly true in a government that is not so dominated by a single political party, and in which the views of individual members might therefore count for more. Following the election that is expected this year, an audit of the 